\title{
In vitro and In vivo One-pot Deracemization of Chiral Amines by Reaction Pathway Control of Enantiocomplementary $\omega$-Transaminases
}

\author{
Sang-Woo Han, Youngho Jang and Jong-Shik Shin*
}

Department of Biotechnology, Yonsei University, Yonsei-Ro 50, Seodaemun-Gu, 03722 Seoul, South Korea

* Corresponding author. E-mail: enzymo@yonsei.ac.kr, Phone: (+82)-2-2123-5884, Fax: (+82)-2-362-7265

\section{CONTENTS}

Thermodynamic calculation of $K_{\mathrm{eq}}$ and $\Delta G$

\section{Supporting Tables}

Table S1. Expression vectors and extinction coefficients of the $\omega$-TAs used in this study.

Table S2. Apparent rate constant per enzyme concentration for ARTA, OATA and OATA

Table S3. Apparent rate constant per enzyme concentration for OATA $\mathrm{W}_{\mathrm{W} 8 \mathrm{~L}}$ and OATA $\mathrm{O}_{\mathrm{R} 47 \mathrm{~A}}$.

Table S4. HPLC analysis conditions for chiral analyses of amines and $\mathbf{4}$.

Table S5. Activity comparison of OATA ${ }_{W 58 \mathrm{~L}}$ and OATAw58L/R417A for $\mathrm{I}^{\mathrm{S}} / \mathrm{III}^{\mathrm{L}}$.

Table S6. Activity comparison of OATA $558 \mathrm{~L}$ and OATAw58L/R417A using S-1a and propanal.

Table S7. Effect of W58L and R417A substitutions in OATA on the partitioning of the amino group of 5 between $\mathbf{2 a}$ and $\mathbf{3}$ during transamination.

Table S8. Enzyme activities of the $E$. coli cells transformed with pCDFDuet-ARTA and/or pRSFDuetOATA $_{W 58 / R 417 A}$.

Table S9. Glycolytic flux at varying feeding amounts of glucose.

\section{Supporting Figures}

Figure S1. SDS-PAGE analysis of OATAw58L/R417A.

Figure S2. Relative positions of W58 and R417 in the X-ray structure of OATA.

Figure S3. Cascade reaction using an ARTA/OATA enzyme pair.

Figure S4. Model prediction of the concentration profiles of $R \mathbf{- 1} \mathbf{a}$ and $\mathbf{3}$ during the cascade reaction with ARTA/OATA $558 \mathrm{~L} / \mathrm{R} 417 \mathrm{~A}$.

Figure S5. Effect of the concentration of $\mathbf{3}$ on the cascade reaction progress.

Figure S6. Reaction progress for deracemization of $\mathbf{1 d}$.

Figure S7. Structural characterizations of isolated $S$-1d.

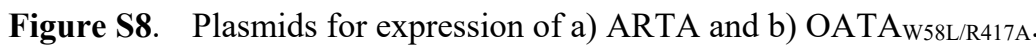

Figure S9. Fermentative conversion of pyruvate in E. coli.

Figure S10. Time-course HPLC analysis of $\mathbf{2 a}$.

Figure S11. A hypothetical pyruvate recycling pathway.

Figure S12. A synthetic deracemization pathway employing L-threonine as an amino acceptor precursor.

Figure S13. Construct of the low copy number plasmid harboring TD and ARTA

\section{HPLC Chromatograms}

\section{References}




\section{Thermodynamic calculation of $K_{\mathrm{eq}}$ and $\Delta G$}

In a previous study, we reported a free energy plot showing relative propensities of deamination/amination of four amino donor/acceptor pairs. ${ }^{1}$ The free energy calculations were based on experimental determination of three equilibrium constants as follows.

Reaction I/III :<smiles>NC([CH+]C(=O)C(=O)O)c1cccc(C(=O)O)c1</smiles>

Reaction 1:<smiles>CCC(N)CC(=O)c1cccc(CCCC(=O)[CH-]C(N)c2ccccc2)c1</smiles>

Reaction 2:

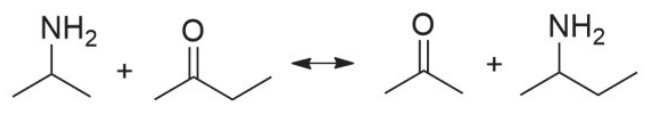$$
K_{\text {eq, } 2}=0.45
$$

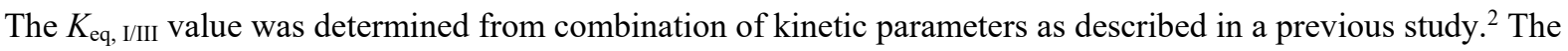
other two equilibrium constants were determined by a curve fitting of reaction quotients as described elsewhere. ${ }^{1}$ Reaction II/III can be represented by reaction I/III - reaction 1 + reaction 2. Likewise, reaction I/II can be represented by reaction 1 - reaction 2 . Therefore, equilibrium constants for reactions II/III and I/II were calculated by combination of the three equilibrium constants above as follows.

Reaction II/III :

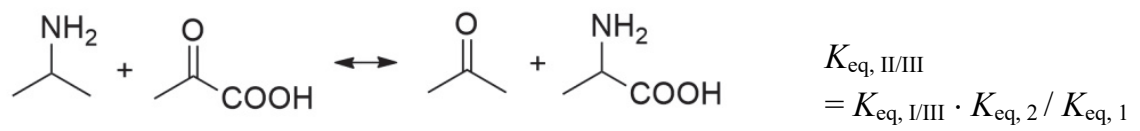

Reaction I/II :

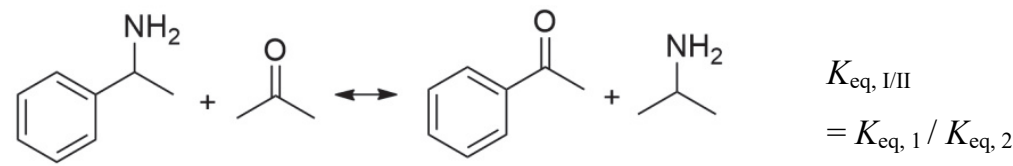

The $\Delta G_{\text {reaction }}$ values were calculated by $-R \mathrm{~T} \ln \left(K_{\text {eq }}\right)$. 


\section{Supporting Tables}

Table S1. Expression vectors and extinction coefficients of the $\omega$-TAs used in this study.

\begin{tabular}{llll}
\hline$\omega$-TA & Plasmids & $\varepsilon_{280}\left(\mathrm{M}^{-1} \mathrm{~cm}^{-1}\right)$ & Source \\
\hline ARTA & pET28-ARTA & 101,885 & Park et al. $^{1}$ \\
OATA & pET28-OATA & 78,076 & Park et al. $^{3}$ \\
OATA $_{\text {W58L }}$ & pET28-OATA $_{\mathrm{W} 58 \mathrm{~L}}$ & 67,076 & Han et al. $^{4}$ \\
OATA $_{\mathrm{W} 58 \mathrm{~L} / \mathrm{R} 417 \mathrm{~A}}$ & pET28-OATA $_{\mathrm{W} 58 \mathrm{~L} / \mathrm{R} 417 \mathrm{~A}}$ & 67,076 & this study \\
\hline
\end{tabular}

Table S2. Apparent rate constant per enzyme concentration for ARTA, OATA and OATAW58L/R417A.

\begin{tabular}{cccc}
\hline \multirow{2}{*}{ Substrate pair } & \multicolumn{3}{c}{$k_{\text {app }} /[E]\left(\mathrm{min}^{-1} \mathrm{mM}^{-1} \mathrm{mM} \text {-enzyme }^{-1}\right)^{a}$} \\
\cline { 2 - 4 } & ARTA & OATA & OATA $_{\mathrm{W} 58 \mathrm{~L} / \mathrm{R} 417 \mathrm{~A}}$ \\
\hline $\mathbf{1 a} / \mathbf{3}$ & 4.00 & 2.40 & $7.64 \times 10^{-2}$ \\
$\mathbf{5} / \mathbf{2 a}$ & $3.60 \times 10^{-4}$ & $7.00 \times 10^{-5}$ & $4.20 \times 10^{-2}$ \\
$\mathbf{5 / 3}$ & $2.73 \times 10^{-3}$ & $1.29 \times 10^{-1}$ & $5.27 \times 10^{-4}$ \\
\hline
\end{tabular}

$\overline{{ }^{a}}$ The $k_{a p p} /[E]$ values were determined by dividing the specific reaction rate in Table 4 by an enzyme concentration.

Table S3. Apparent rate constant per enzyme concentration for OATA ${ }_{\mathrm{W} 58 \mathrm{~L}}$ and OATAR417A.

\begin{tabular}{ccc}
\hline \multirow{2}{*}{ Reaction } & \multicolumn{2}{c}{$k_{\text {app }} /[E]\left(\mathrm{min}^{-1} \mathrm{mM}^{-1} \mathrm{mM}_{\text {enzyme }}^{-1}\right)$} \\
\cline { 2 - 3 } & OATA $_{\text {W5L }}$ & OATA $_{\text {R } 417 \mathrm{~A}}$ \\
\hline $\mathbf{1 a} / \mathbf{3}$ & 2.40 & $7.64 \times 10^{-2}$ \\
$\mathbf{5} / \mathbf{2 a}$ & $4.20 \times 10^{-2}$ & $7.00 \times 10^{-5}$ \\
$\mathbf{5 / 3}$ & $1.29 \times 10^{-1}$ & $5.27 \times 10^{-4}$ \\
\hline
\end{tabular}


Table S4. HPLC analysis conditions for chiral analyses of amines and $\mathbf{4 .}$

\begin{tabular}{|c|c|c|c|c|}
\hline \multirow{2}{*}{ Analyte } & \multirow{2}{*}{ Column } & \multirow{2}{*}{ Elution conditions } & \multicolumn{2}{|c|}{ Retention time (min) } \\
\hline & & & $R$-form & $S$-form \\
\hline 1a & Crownpak CR(-) & water (perchloric acid, $\mathrm{pH}$ 2), $0.8 \mathrm{~mL} / \mathrm{min}$ & 11.0 & 13.9 \\
\hline $1 b$ & Crownpak CR(-) & water (perchloric acid, $\mathrm{pH}$ 2), $0.6 \mathrm{~mL} / \mathrm{min}$ & 17.7 & 23.4 \\
\hline $1 \mathrm{c}$ & Crownpak CR(-) & water (perchloric acid, $\mathrm{pH}$ 2), $0.6 \mathrm{~mL} / \mathrm{min}$ & 31.9 & 39.6 \\
\hline 1d & Crownpak CR-I(-) & $\begin{array}{c}85 / 15 \%(\mathrm{v} / \mathrm{v}) \text { water (perchloric acid, } \\
\mathrm{pH} 2) / \text { acetonitrile, } 0.4 \mathrm{~mL} / \mathrm{min}\end{array}$ & 9.7 & 11.5 \\
\hline 1e & Symmetry C18 & $80 / 20 \%(\mathrm{v} / \mathrm{v}) \mathrm{MeOH} /$ water ${ }^{a}, 0.8 \mathrm{~mL} / \mathrm{min}$ & 7.1 & 8.0 \\
\hline 1f & Symmetry C18 & $85 / 15 \%(\mathrm{v} / \mathrm{v}) \mathrm{MeOH} /$ water, ${ }^{a} 0.8 \mathrm{~mL} / \mathrm{min}$ & 7.9 & 9.1 \\
\hline 4 & Symmetry C18 & $45 / 55 \%(\mathrm{v} / \mathrm{v}) \mathrm{MeOH} /$ water, ${ }^{a} 1 \mathrm{~mL} / \mathrm{min}$ & 16.0 & 9.7 \\
\hline
\end{tabular}

${ }^{a}$ Both $\mathrm{MeOH}$ and water contained $0.1 \%(\mathrm{v} / \mathrm{v})$ trifluoroacetic acid.

Table S5. Activity comparison of OATA $558 \mathrm{~L}$ and OATA ${ }_{W 58 \mathrm{~L} / \mathrm{R} 417 \mathrm{~A}}$ for $\mathrm{I}^{\mathrm{S}} / \mathrm{III}^{\mathrm{L}}$.

\begin{tabular}{lc}
\hline Enzyme & \left.${\text { Specific reaction } \text { rate }^{a}\left(\mu \mathrm{M} \mathrm{min}^{-1} \mu \mathrm{M} \text {-enzyme }\right.}^{-1}\right)$ \\
\hline OATA $_{\mathrm{W} 58 \mathrm{~L}}$ & $1280 \pm 30$ \\
OATA $_{\mathrm{W} 58 \mathrm{~L} / \mathrm{R} 417 \mathrm{~A}}$ & $2.1 \pm 0.5^{b}$ \\
\hline
\end{tabular}

${ }^{a}$ Reaction conditions: $5 \mathrm{mM} S$-1a and $5.5 \mathrm{mM} 3$ in $50 \mathrm{mM}$ phosphate buffer (pH 7) at $37{ }^{\circ} \mathrm{C}$. Produced $2 \mathbf{a}$ was analyzed by HPLC. ${ }^{b}$ This is taken from Table 4.

Table S6. Activity comparison of OATA $\mathrm{W}_{58 \mathrm{~L}}$ and OATA $\mathrm{W}_{\mathrm{W} 8 \mathrm{~L} / \mathrm{R} 417 \mathrm{~A}}$ using $S$-1a and propanal.

\begin{tabular}{lc}
\hline Enzyme & \left.${\text { Specific reaction } \text { rate }^{a}\left(\mu \mathrm{M} \mathrm{min}^{-1} \mu \mathrm{M} \text {-enzyme }\right.}^{-1}\right)$ \\
\hline OATA $_{\mathrm{W} 58 \mathrm{~L}}$ & 560 \\
OATA $_{\mathrm{W} 58 \mathrm{~L} / \mathrm{R} 417 \mathrm{~A}}$ & 530 \\
\hline
\end{tabular}

${ }^{a}$ Reaction conditions: $10 \mathrm{mM} \mathrm{S-1a,} 10 \mathrm{mM}$ propanal, $50 \mathrm{mM}$ phosphate buffer $(\mathrm{pH} 7)$ at $37{ }^{\circ} \mathrm{C}$. Produced $\mathbf{2 a}$ was analyzed by HPLC. 
Table S7. Effect of W58L and R417A substitutions in OATA on the partitioning of the amino group of 5 between $\mathbf{2 a}$ and $\mathbf{3}$ during transamination.

\begin{tabular}{lcc}
\hline \multirow{2}{*}{ Enzyme } & \multicolumn{2}{c}{ Amination product $^{a}(\mathrm{mM})$} \\
\cline { 2 - 3 } & $S$-1a & L-4 \\
\hline OATA & not detectable & 2.0 \\
OATA $_{\mathrm{W} 58 \mathrm{~L} / \mathrm{R} 417 \mathrm{~A}}$ & 0.46 & 0.01 \\
\hline
\end{tabular}

${ }^{a}$ Reaction conditions: $100 \mathrm{mM} \mathrm{5,10} \mathrm{mM} \mathrm{2a,} 10 \mathrm{mM} 3$ and $5 \mu \mathrm{M}$ enzyme in $50 \mathrm{mM}$ phosphate buffer (pH 7) at $37{ }^{\circ} \mathrm{C}$ for $10 \mathrm{~min}$. Produced $S$-1a was analyzed by chiral HPLC using a Crownpak CR(-) column. Produced L-4 was analyzed by HPLC after derivatization with the Marfey's reagent.

Table S8. Enzyme activities of the $E$. coli cells transformed with pCDFDuet-ARTA and/or pRSFDuet$\mathrm{OATA}_{\mathrm{W} 58 \mathrm{~L} / \mathrm{R} 417 \mathrm{~A}}$.

\begin{tabular}{lcc}
\hline \multirow{2}{*}{ Expression plasmid in $E$. coli } & \multicolumn{2}{c}{ Specific enzyme activity $^{a}(\mathrm{U} / \mathrm{mg}$ dcw $)$} \\
\cline { 2 - 3 } pCDFDuet-ARTA & ARTA $^{b}$ & OATA $_{\text {W58L/R417A }}{ }^{c}$ \\
pRSFDuet-OATA & $0.72 \pm 0.04$ & n. $^{d}$ \\
both plasmids & n. d. & $0.86 \pm 0.05$ \\
\hline
\end{tabular}

${ }^{a}$ It represents an enzyme activity per dry cell weight and the activity assay was carried out using the $E$. coli cells transformed with the expression plasmid. ${ }^{b}$ Reaction conditions: $10 \mathrm{mM} R-\mathbf{1 a}$ and $10 \mathrm{mM} 3$ in $50 \mathrm{mM}$ phosphate buffer (pH 7) at $37{ }^{\circ} \mathrm{C}$ for $10 \mathrm{~min}$. Produced 2a was analyzed by HPLC. ${ }^{c}$ Reaction conditions: $10 \mathrm{mM} S$-1a and $10 \mathrm{mM} 3$ in $50 \mathrm{mM}$ phosphate buffer $(\mathrm{pH} 7)$ at $37{ }^{\circ} \mathrm{C}$ for $10 \mathrm{~min}$. Produced 2a was analyzed by HPLC. ${ }^{d}$ not detectable.

Table S9. Glycolytic flux at varying feeding amounts of glucose. ${ }^{a}$

\begin{tabular}{ccc}
\hline $\begin{array}{c}\text { Glucose feeding } \\
\text { (molar eq. to 50 mM rac-1a) }\end{array}$ & $\begin{array}{c}\text { Glucose leftover at 18 } \mathrm{h} \\
(\mathrm{mM})\end{array}$ & $\begin{array}{c}\text { Glucose consumption at } 18 \mathrm{~h} \\
(\mathrm{mM})\end{array}$ \\
\hline 0.15 & 0 & 7.5 \\
0.25 & 0 & 12.5 \\
0.5 & 5.1 & 19.9 \\
0.75 & 15.1 & 22.4 \\
1 & 25.6 & 24.4 \\
\hline
\end{tabular}

${ }^{a}$ Reaction conditions were the same as those for Fig. 5 . 


\section{Supporting Figures}

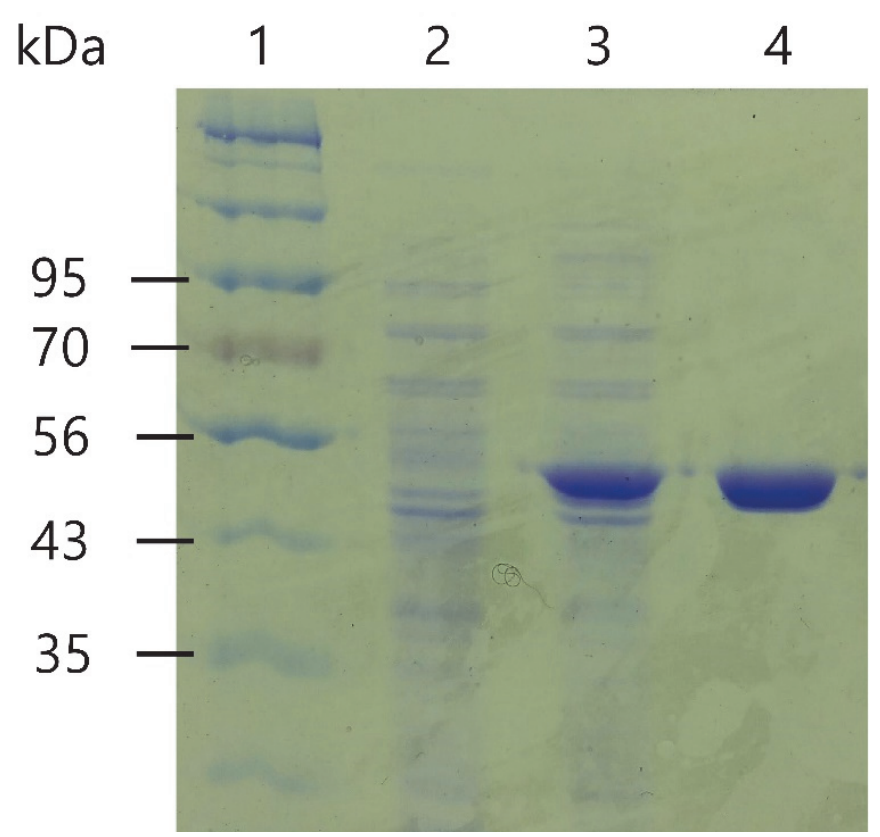

Figure S1. SDS-PAGE analysis of OATA ${ }_{W 58 L / R 417 A}$. Lanes: 1 marker, 2 cell-free extract prepared with $E$. coli BL21(DE3) cells not carrying an expression vector, 3 cell-free extract prepared with cells expressing OATA $_{W 58 L / R 417 A}, 4$ purified OATA ${ }_{W 58 L / R 417 A}$. Molecular weight of a OATA ${ }_{W 58 L / R 417 A}$ monomer deduced from amino acid sequence is $51 \mathrm{kDa}$. 


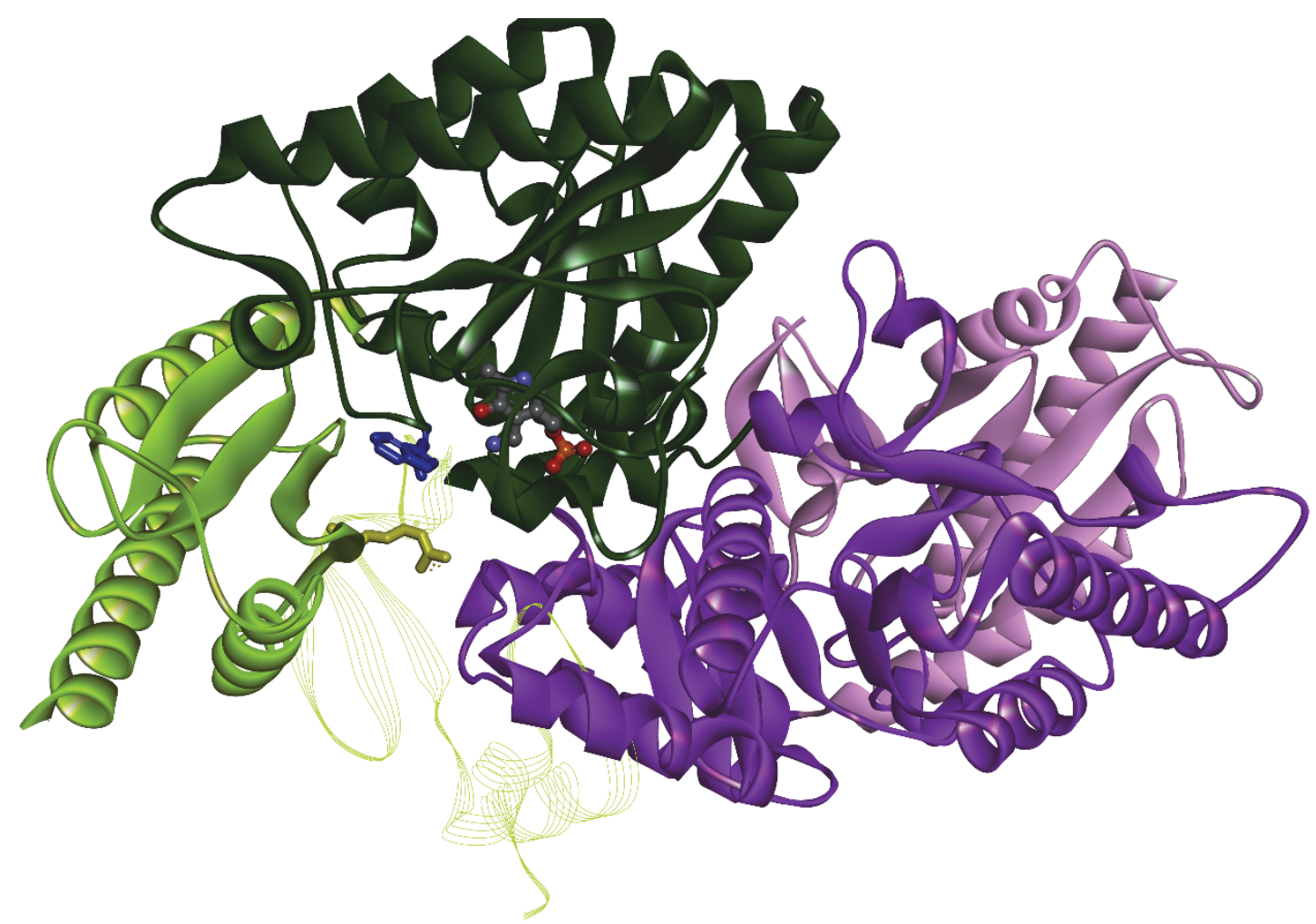

Figure S2. Relative positions of W58 and R417 in the X-ray structure of OATA (PDB ID: 5GHF). Chain A and $\mathrm{B}$ in the dimeric structure of OATA are colored green and purple, respectively. The large (residues 67-345) and small (residues 1-66 and 346-456) domains are shown in dark and light colors, respectively. The 1-66 and 346456 subdomains of the small domain of chain A are represented by line and solid ribbons, respectively, and are separated by the large domain of chain A. W58 and R417 in chain A are shown as blue and yellows sticks, respectively. PMP in chain A is represented in a ball-and-stick model. 


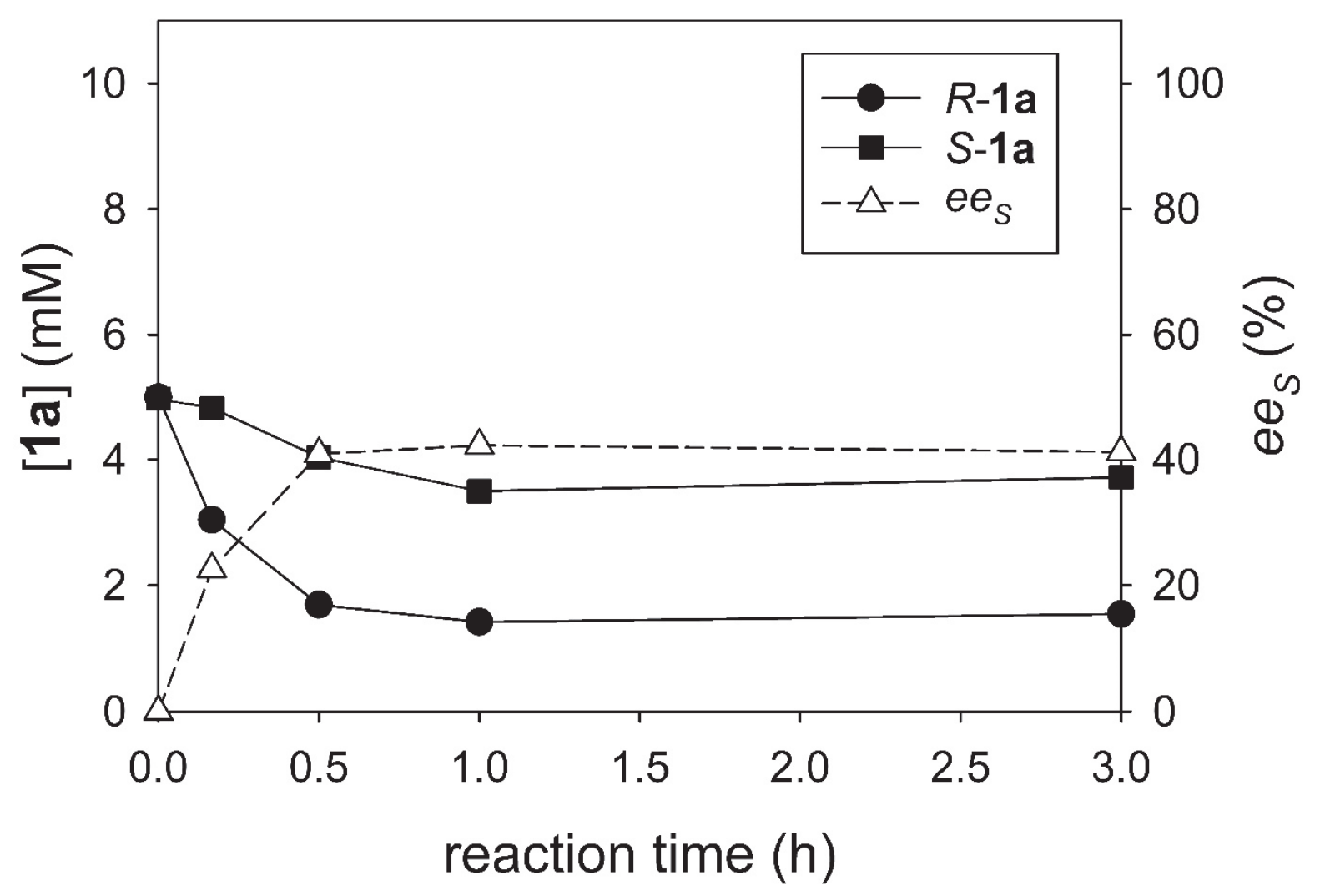

Figure S3. Cascade reaction using an ARTA/OATA enzyme pair. Reaction conditions were $10 \mathrm{mM}$ rac-1a, 5.5 mM 3, $100 \mathrm{~mm} 5$ and $10 \mu \mathrm{M}$ both $\omega$-TAs in $50 \mathrm{~mm}$ phosphate buffer $(\mathrm{pH} 7.0)$ at $37^{\circ} \mathrm{C}$ 


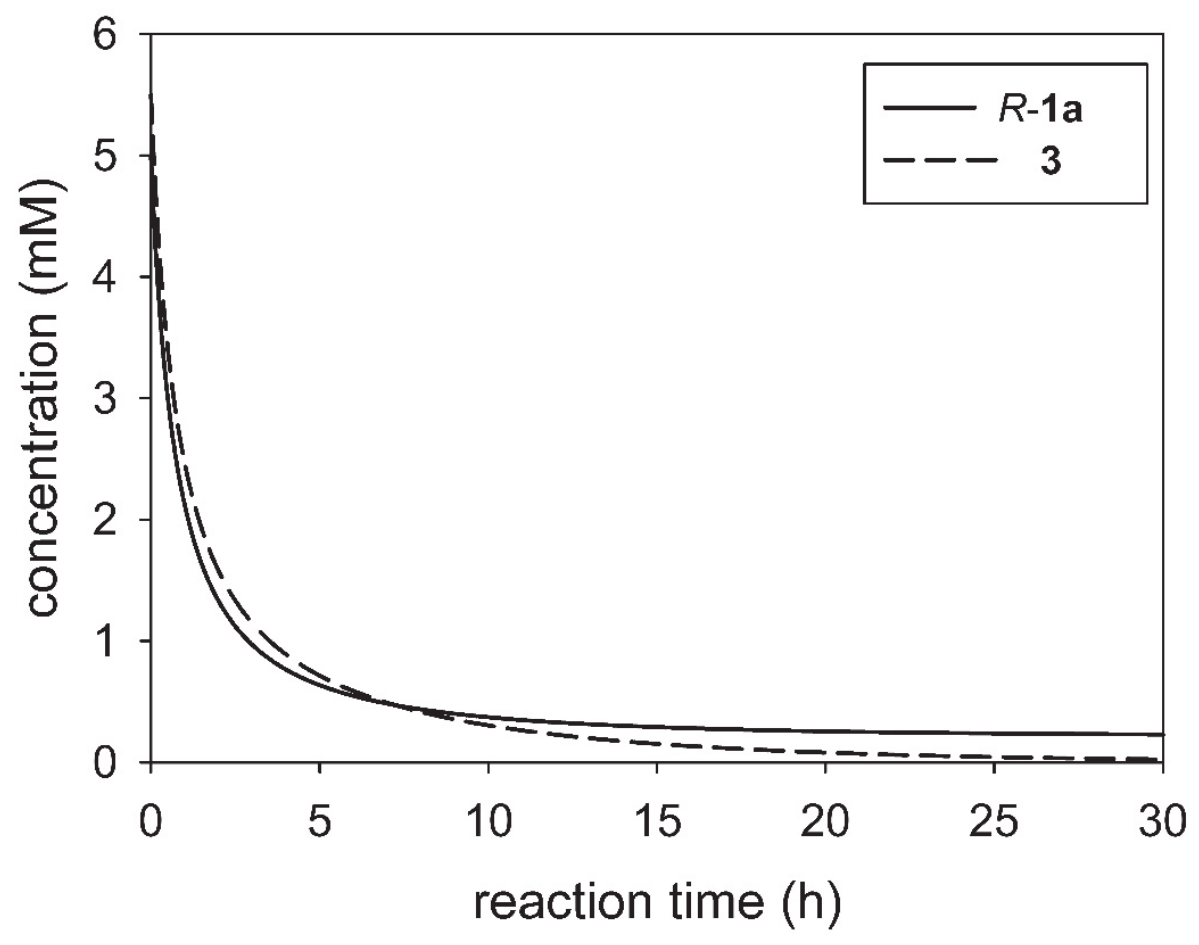

Figure S4. Model prediction of the concentration profiles of $R-\mathbf{1 a}$ and $\mathbf{3}$ during the cascade reaction with ARTA/OATAw58L/R417A. Concentration of $\mathbf{3}$ becomes lower than that of $R-\mathbf{1 a}$ at $7.2 \mathrm{~h}$. Simulation conditions were

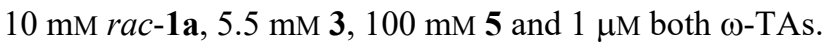



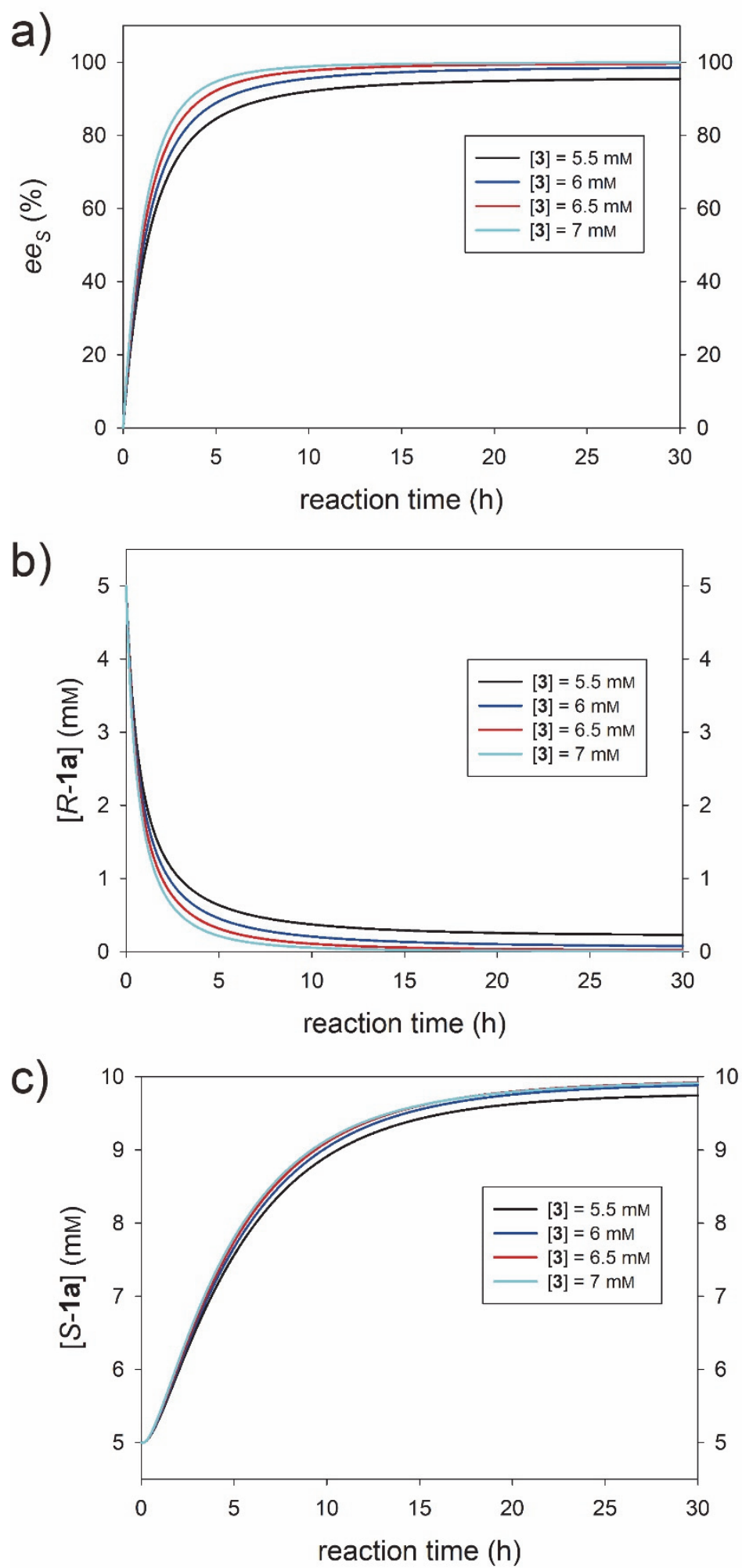

Figure S5. Effect of concentration of $\mathbf{3}$ on the cascade reaction progress. Time-dependent changes in a) $e e_{S}, \mathrm{~b}$ ) $[R-1 \mathbf{a}]$ and c) $[S-1 \mathbf{a}]$ were plotted at varying initial concentrations of $\mathbf{3}$. The $e e_{S}$ values at $30 \mathrm{~h}$ were $95.4,98.5$, 99.6 and $99.9 \%$ in ascending order of concentration of 3 (i.e., 5.5 to $7 \mathrm{mM}$ ). Likewise, the $[R-1 \mathbf{a}]$ values at $30 \mathrm{~h}$ were $0.23,0.08,0.02$ and $0.01 \mathrm{mM}$. Similarly, the $[S-1 \mathbf{a}]$ values at $30 \mathrm{~h}$ were $9.75,9.88,9.92$ and $9.91 \mathrm{mM}$. Simulation conditions were $10 \mathrm{~mm} \mathrm{rac-1a}, 5.5-7 \mathrm{mM} \mathrm{3,100} \mathrm{mM} 5$ and $1 \mu \mathrm{M}$ both ARTA and OATAw58L/R417A. 


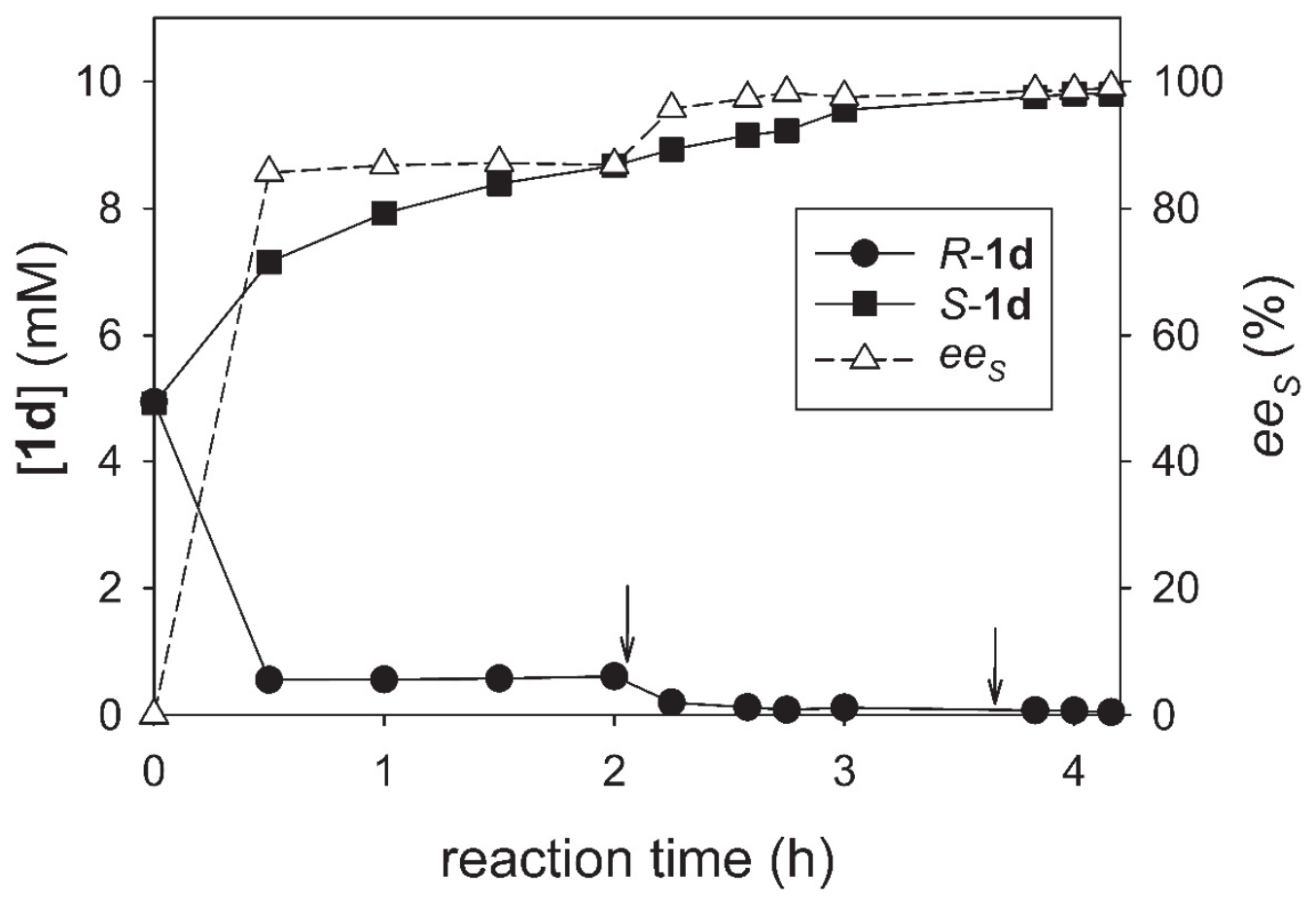

Figure S6. Reaction progress for deracemization of 1d. Reaction conditions were $10 \mathrm{mM} \mathrm{rac}-\mathbf{1 d}, 6.5 \mathrm{mM} \mathrm{3,100}$ mM 5, $10 \mu \mathrm{M}$ ARTA, $100 \mu \mathrm{M}$ OATA ${ }_{\mathrm{W} 58 \mathrm{~L} / \mathrm{R} 417 \mathrm{~A}}$ and $15 \% \mathrm{v} / \mathrm{v}$ DMSO in $50 \mathrm{mM}$ phosphate buffer $(\mathrm{pH} 7)$ at $37^{\circ} \mathrm{C}$ and 460 Torr. Arrows represent additional feeding of $\mathbf{3}$ at 2.1 and $3.7 \mathrm{~h}$ (final concentration of 1 and $0.3 \mathrm{mM}$, respectively). 
a)
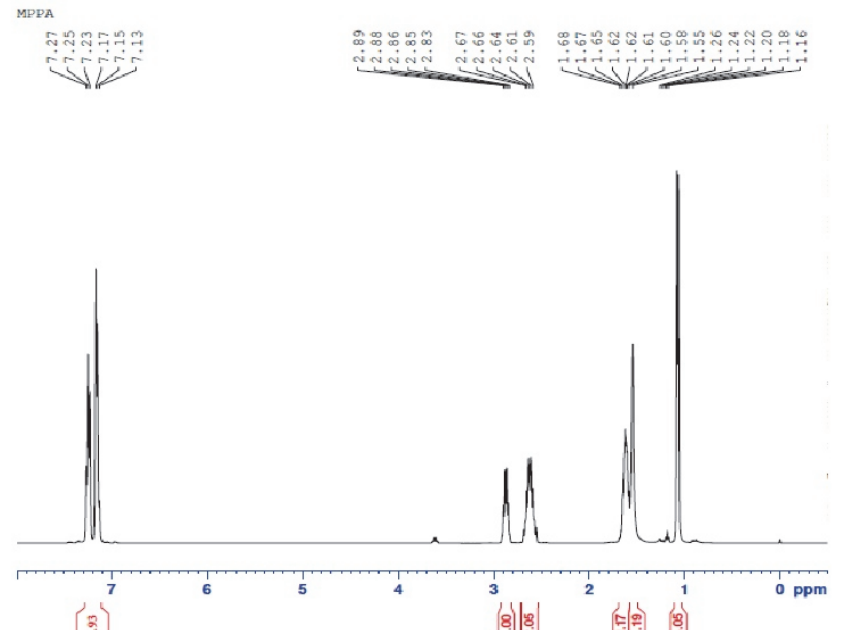

b)
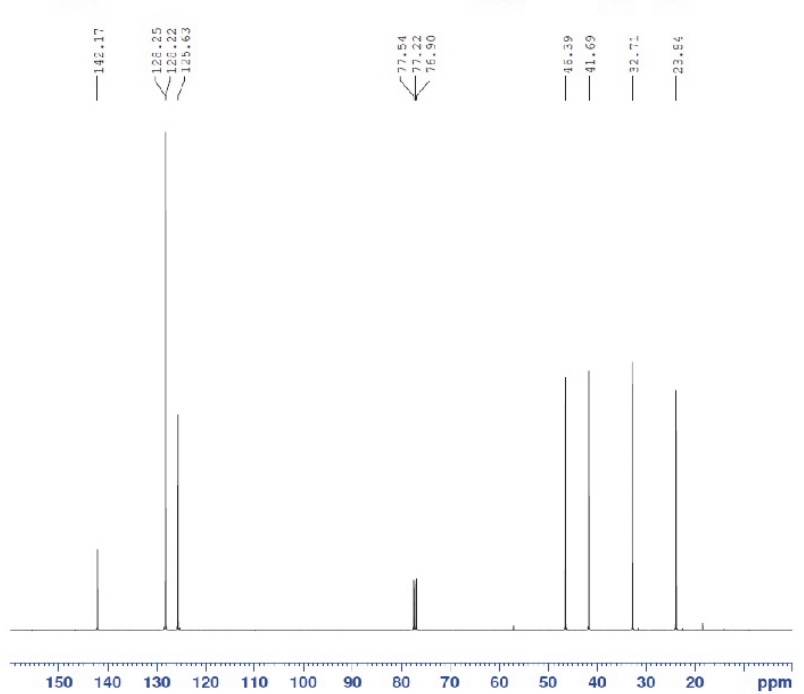

c)

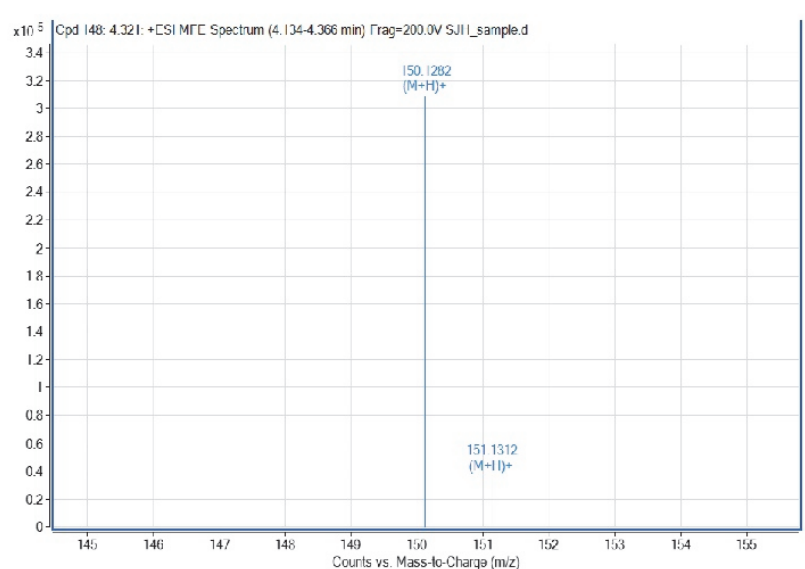

Figure S7. Structural characterizations of isolated $S$-1d. a) ${ }^{1} \mathrm{H}-\mathrm{NMR}\left(400 \mathrm{MHz}, \mathrm{CDCl}_{3}\right): \delta(\mathrm{ppm})$ 1.05-1.07(d, $\left.3 \mathrm{H}, \mathrm{CH}_{3}\right), 1.55\left(\mathrm{~s}, 2 \mathrm{H}, \mathrm{NH}_{2}\right), 1.58-1.68\left(\mathrm{~m}, 2 \mathrm{H}, \mathrm{CH}_{2}\right), 2.59-2.67\left(\mathrm{~m}, 2 \mathrm{H}, \mathrm{CH}_{2}\right), 2.83-2.89(\mathrm{~m}, 1 \mathrm{H}, \mathrm{CH}), 7.13-7.27(\mathrm{~m}$, 5H, CH). b) ${ }^{13} \mathrm{C}-\mathrm{NMR}\left(100 \mathrm{MHz}, \mathrm{CDCl}_{3}\right): \delta$ (ppm) 23.84, 32.71, 41.69, 46.43, 125.63, 128.22, 128.25, 142.17. c) HRMS (ESI): $m / z[\mathrm{M}+\mathrm{H}]^{+}$; calc'd for $\mathrm{C}_{10} \mathrm{H}_{15} \mathrm{~N}, 150.1279$; found, 150.1282 . 
a)

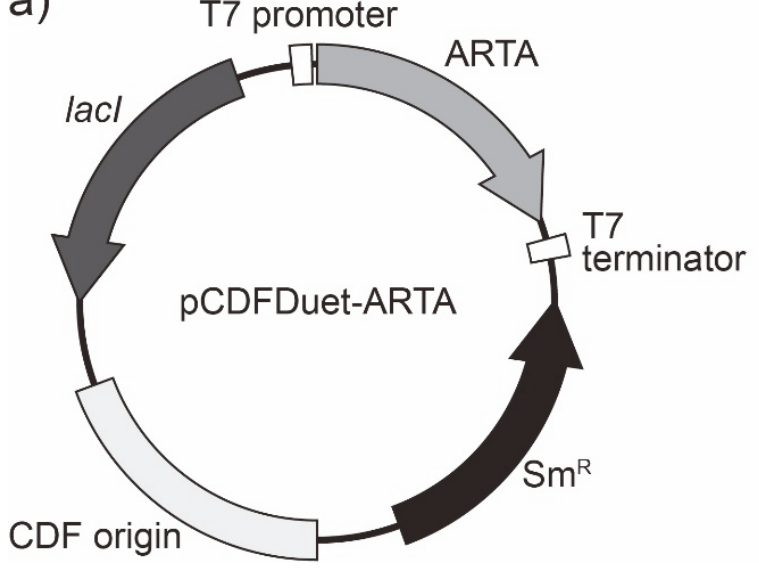

b)

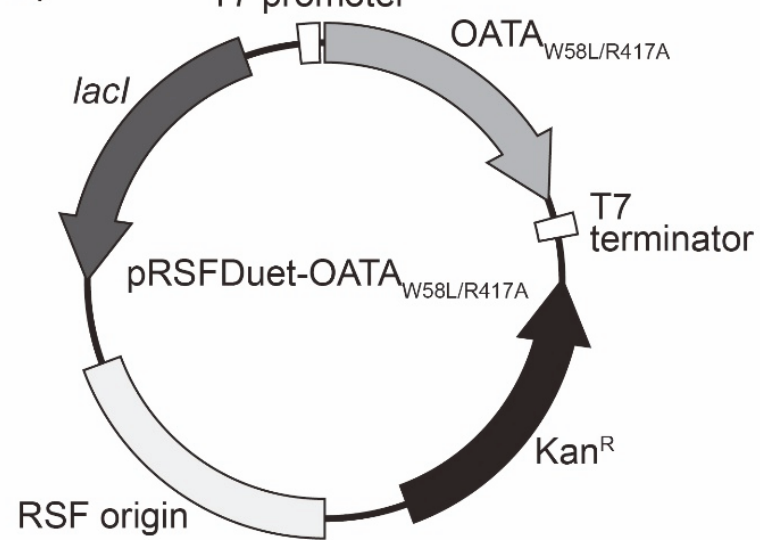

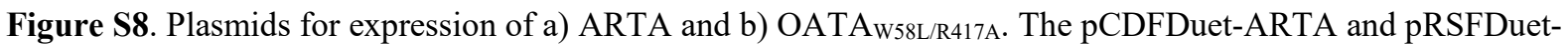
OATA ${ }_{W 58 L / R 417 A}$ plasmids carry streptomycin $\left(\mathrm{Sm}^{\mathrm{R}}\right)$ and kanamycin $\left(\mathrm{Kan}^{\mathrm{R}}\right)$ resistance markers, respectively. The CDF and RSF replicons lead to plasmid copy numbers of 20-30 and $>100$, respectively. 

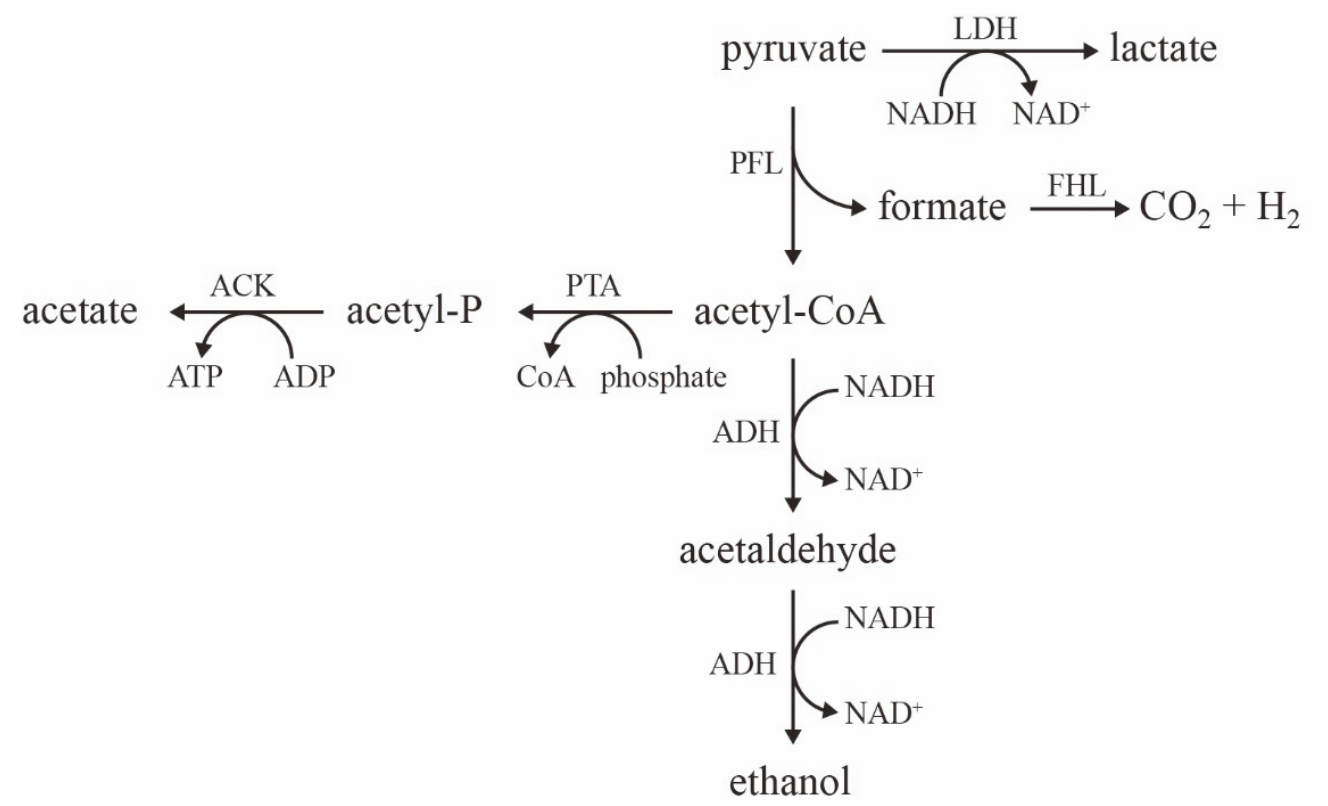

Figure S9. Fermentative conversion of pyruvate in E. coli. Abbreviations used are: ACK, acetate kinase; ADH, alcohol dehydrogenase; FHL, formate hydrogen-lyase; LDH, lactate dehydrogenase; PFL, pyruvate formate-lyase; PTA, phosphate acetyltransferase. 
a)
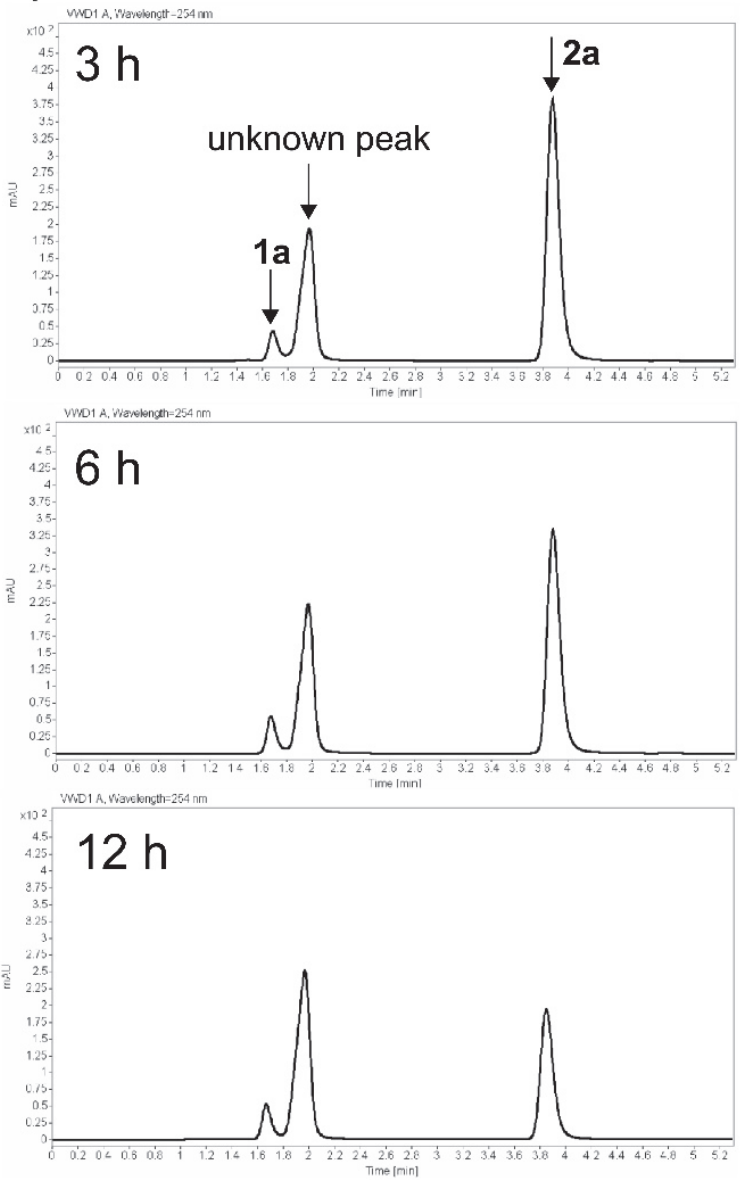

$18 \mathrm{~h}$ b)
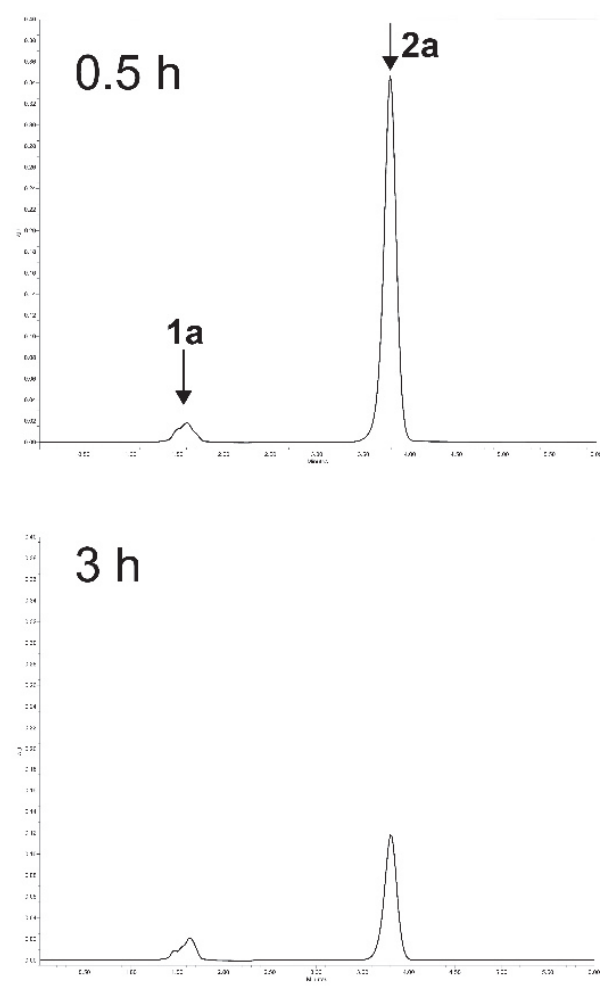

$6 \mathrm{~h}$
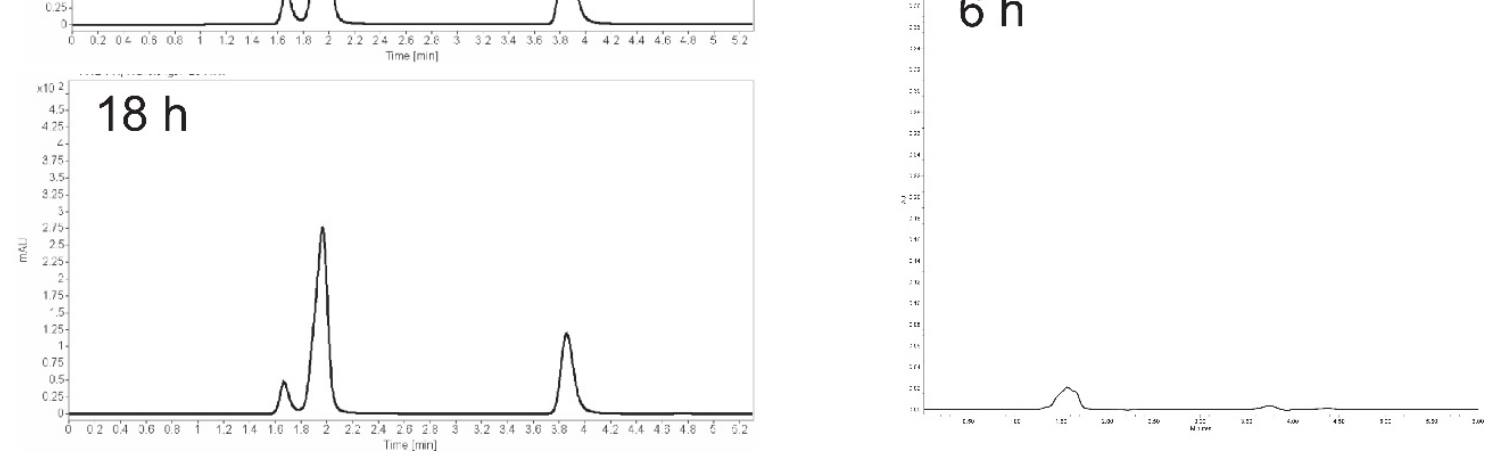

Figure S10. Time-course HPLC analysis of 2a. a) In vivo deracemization shown in Fig. 5A. b) In vitro deracemization shown in Fig. 3B. 


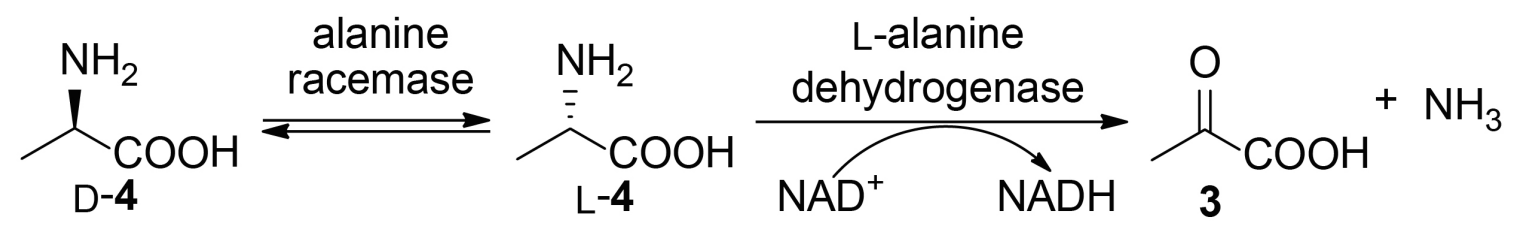

Figure S11. A hypothetical pyruvate recycling pathway. 


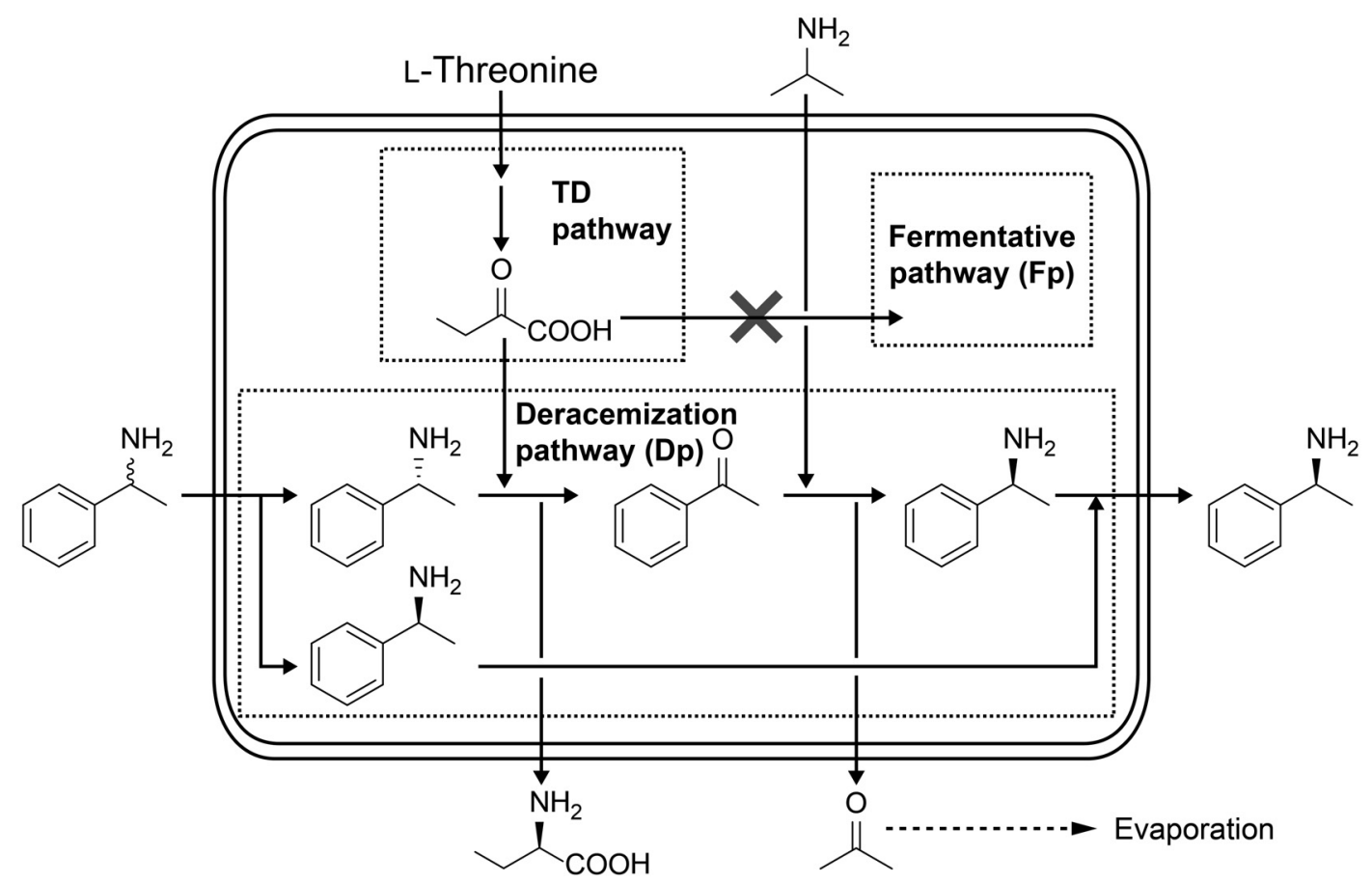

Figure S12. A synthetic deracemization pathway employing L-threonine as an amino acceptor precursor. Threonine deaminase (TD) pathway converts L-threonine to 2-oxobutyrate which enters Dp and then is converted to D-homoalanine. Note that 2-oxobutyrate cannot enter Fp. 


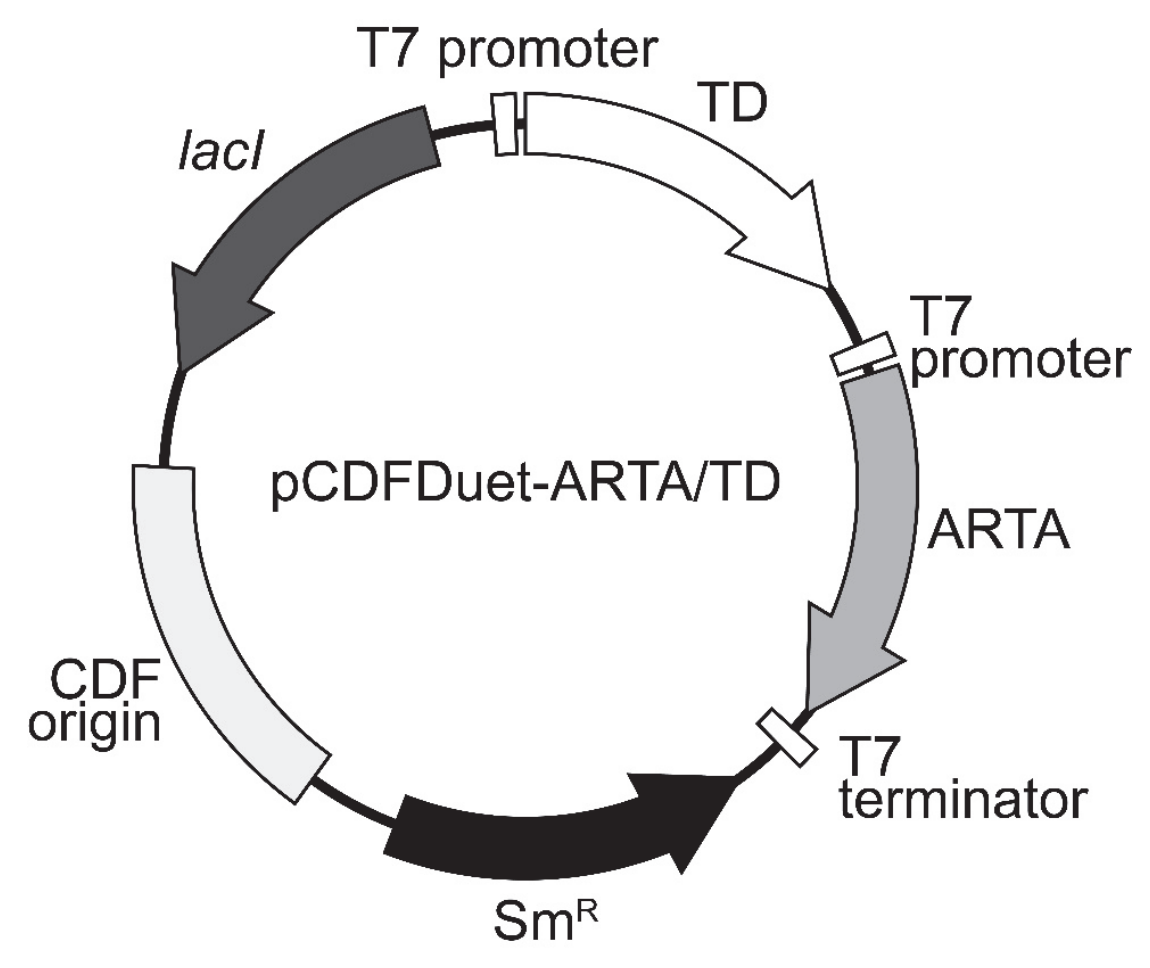

Figure S13. Construct of the low copy number plasmid harboring TD and ARTA. 


\section{HPLC Chromatograms}

\section{HPLC chromatograms of 1a}

Before deracemization (YL9300 HPLC system)

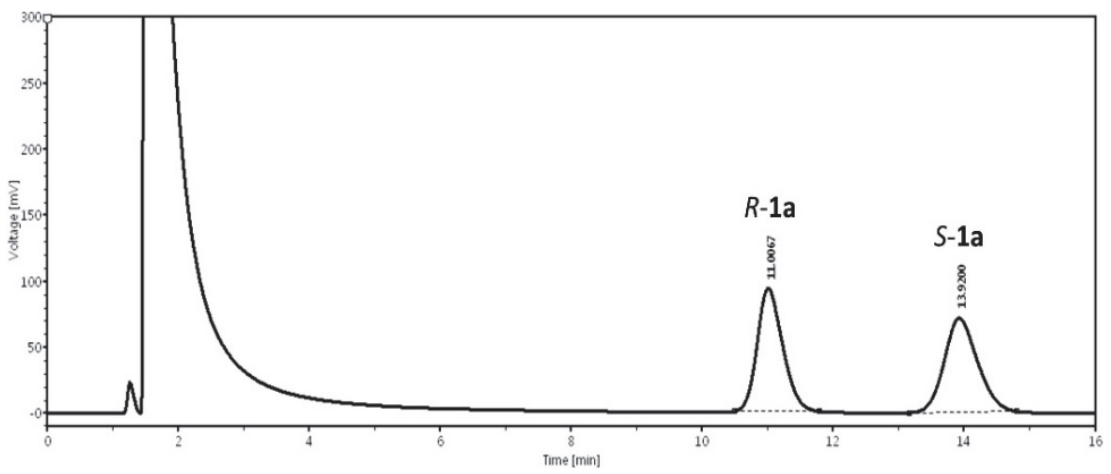

After in vitro deracemization of $10 \mathrm{mM} \mathrm{rac-1a(YL9300} \mathrm{HPLC} \mathrm{system)}$

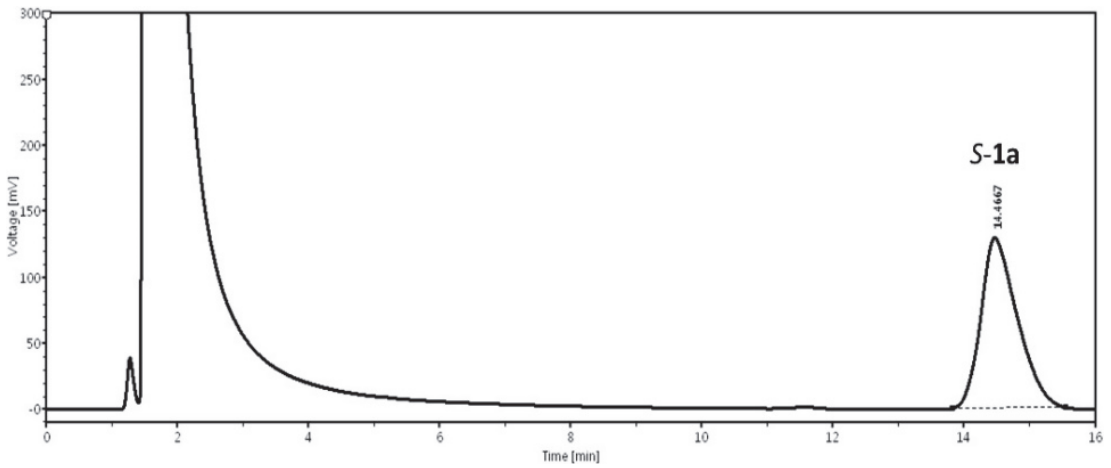

After in vivo deracemization of $50 \mathrm{mM} \mathrm{rac}-1 \mathrm{a}$ using $25 \mathrm{mM}$ glucose. (Alliance HPLC system)

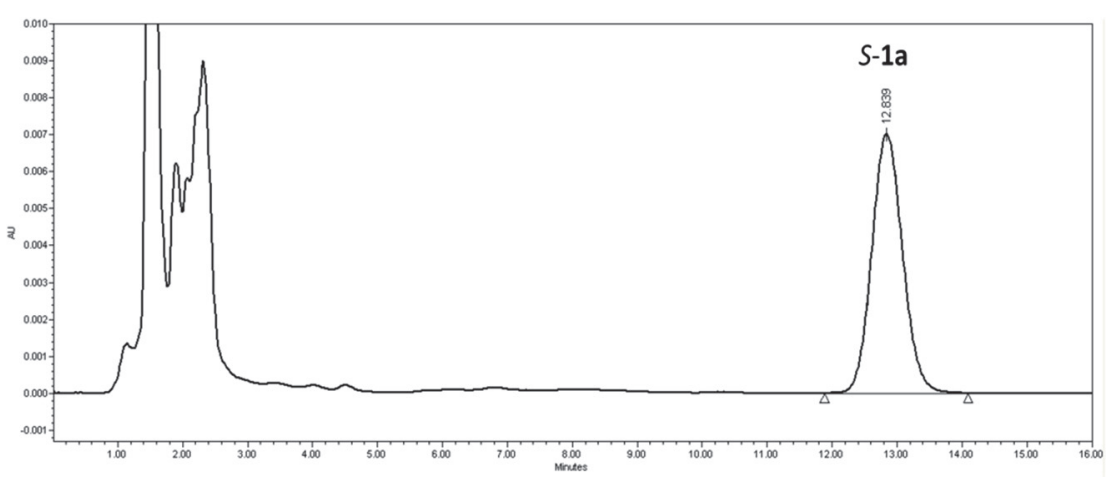


HPLC chromatograms of $\mathbf{1 b}$

Before deracemization (Alliance HPLC system)

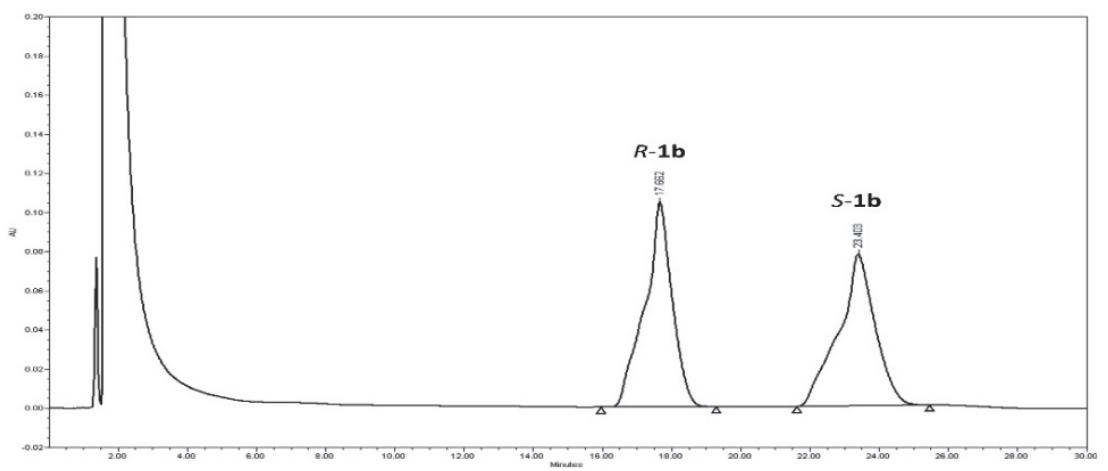

After deracemization of $10 \mathrm{mM} \mathrm{rac}-\mathbf{1 b}$ (Alliance HPLC system)

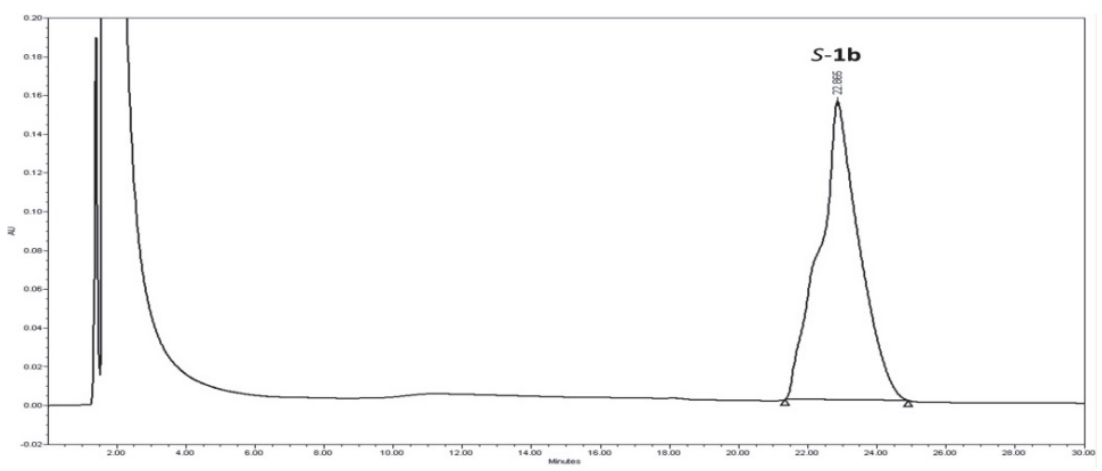

\section{$\underline{\text { HPLC chromatograms of } 1 \mathrm{c}}$}

Before deracemization (YL9300 HPLC system)

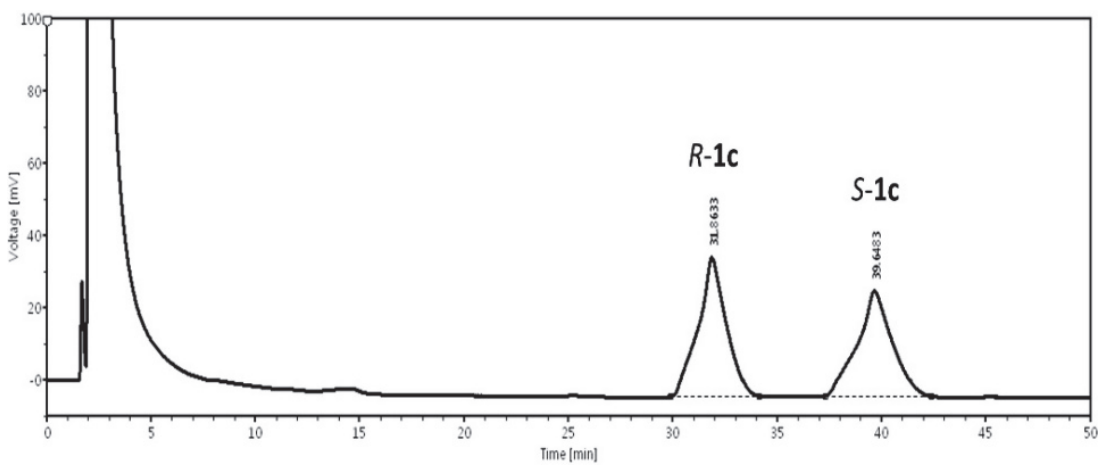

After deracemization of $10 \mathrm{mM} \mathrm{rac}$-1c (YL9300 HPLC system)

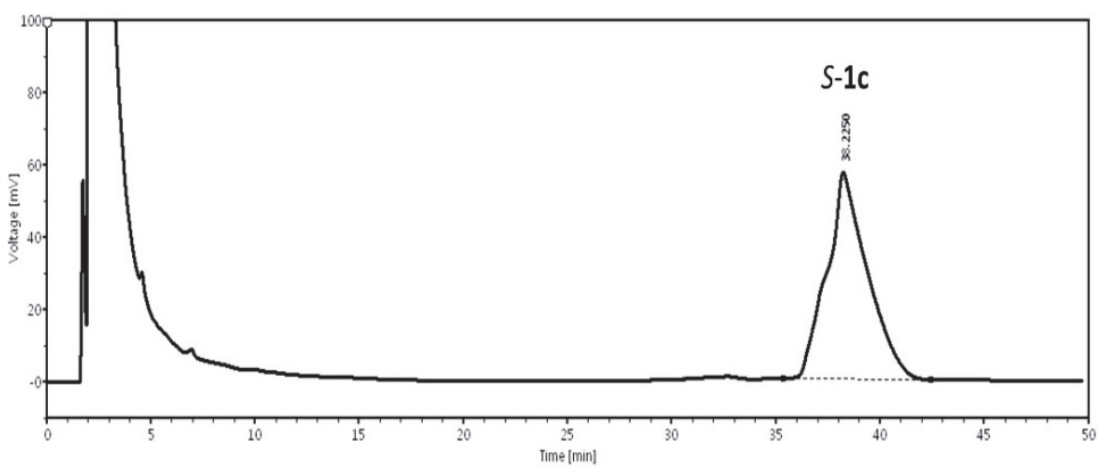


HPLC chromatograms of 1d

Before deracemization (YL9300 HPLC system)

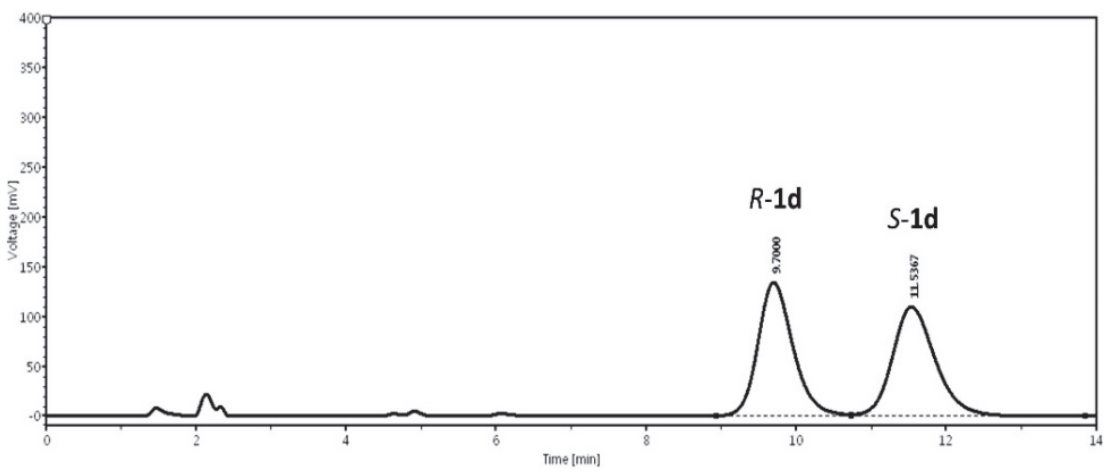

After deracemization of $100 \mathrm{mM} \mathrm{rac-1d}$ (YL9300 HPLC system)

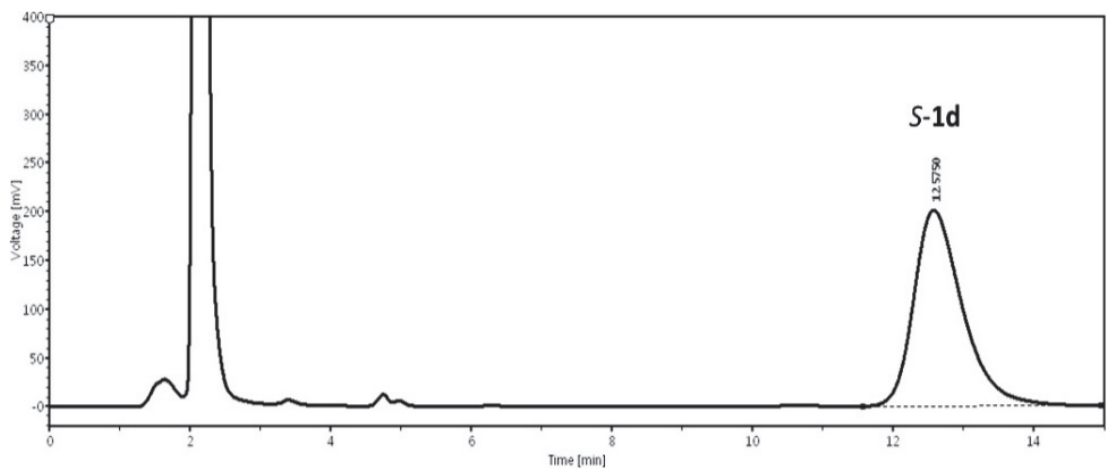

HPLC chromatograms of 1e

Before deracemization (YL9300 HPLC system)

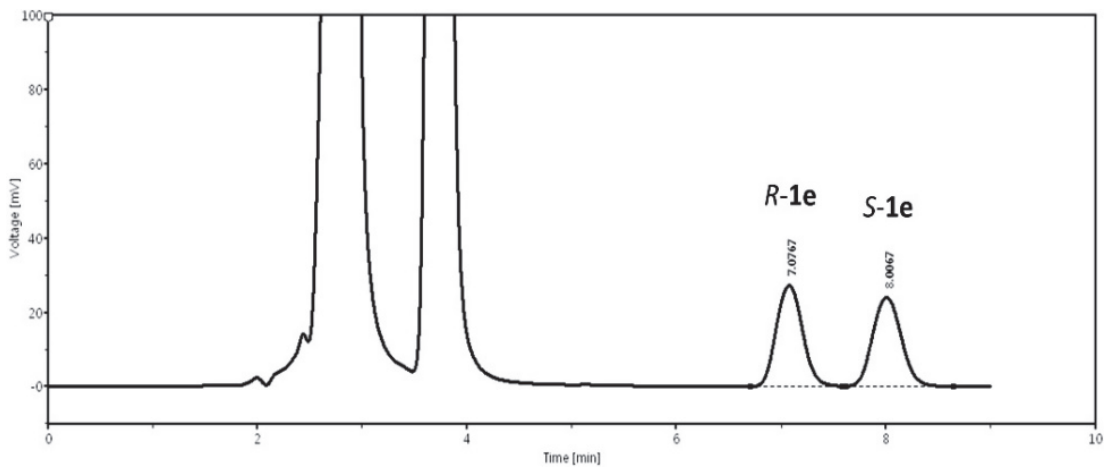

After deracemization of $10 \mathrm{mM} \mathrm{rac}$-1e (YL9300 HPLC system)

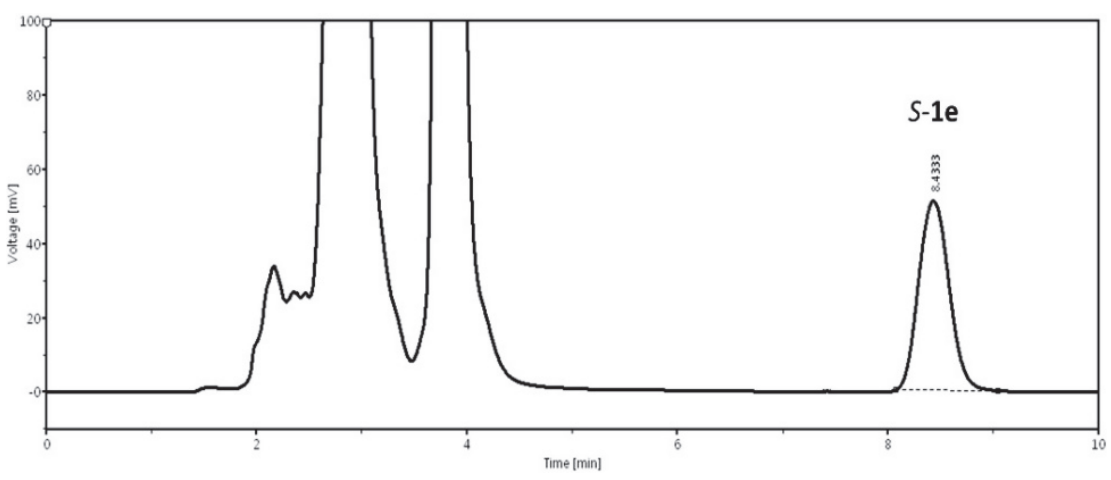


$\underline{\text { HPLC chromatograms of } \mathbf{1 f}}$

Before deracemization (YL9300 HPLC system)

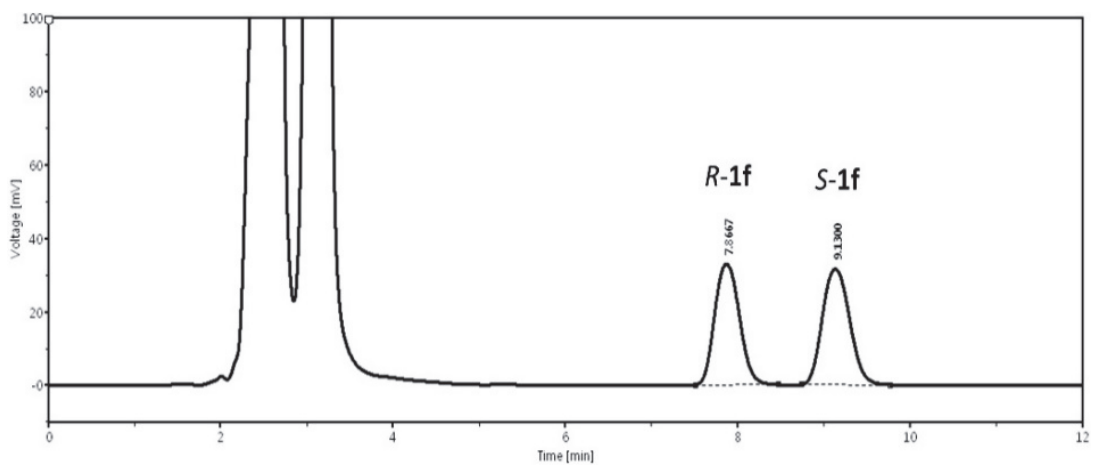

After deracemization of $10 \mathrm{mM} \mathrm{rac}-\mathbf{1 f}$ (YL9300 HPLC system)

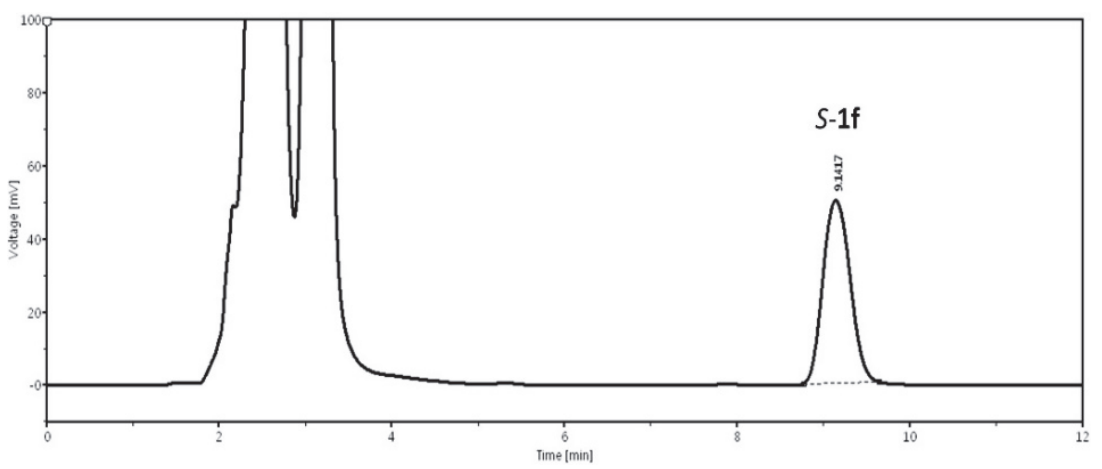

HPLC chromatograms of metabolites and glucose

10 mM Glucose (RI detector, 1260 Infinity II LC System)

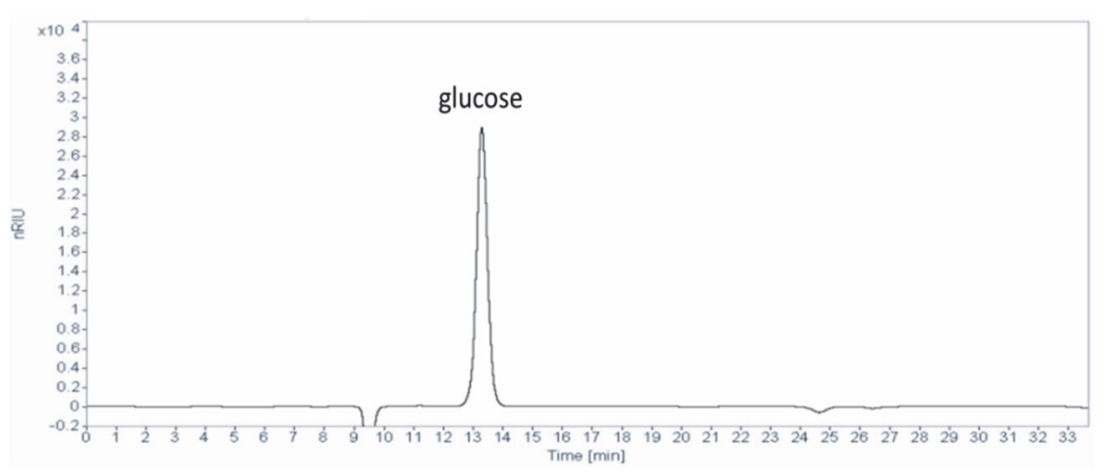

10 mM Ethanol (RI detector, 1260 Infinity II LC System)

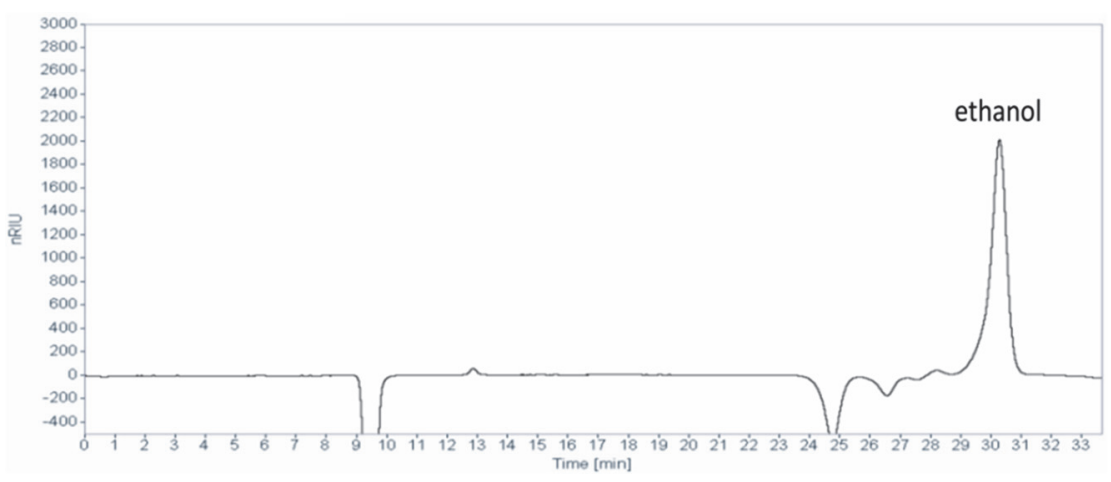


$1 \mathrm{mM} 3$ (UV detector, 1260 Infinity II LC System)

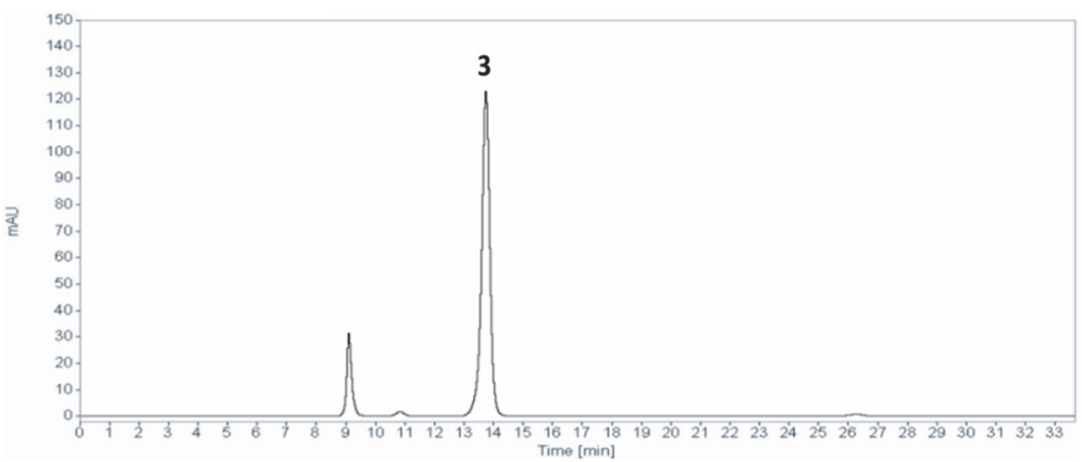

10 mM Lactic acid (UV detector, 1260 Infinity II LC System)

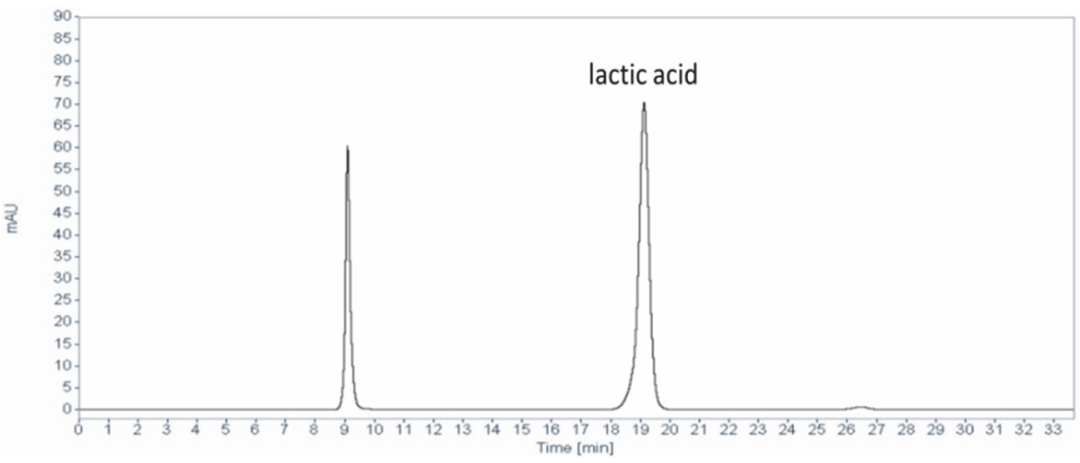

$10 \mathrm{mM}$ Acetic acid (UV detector, 1260 Infinity II LC System)

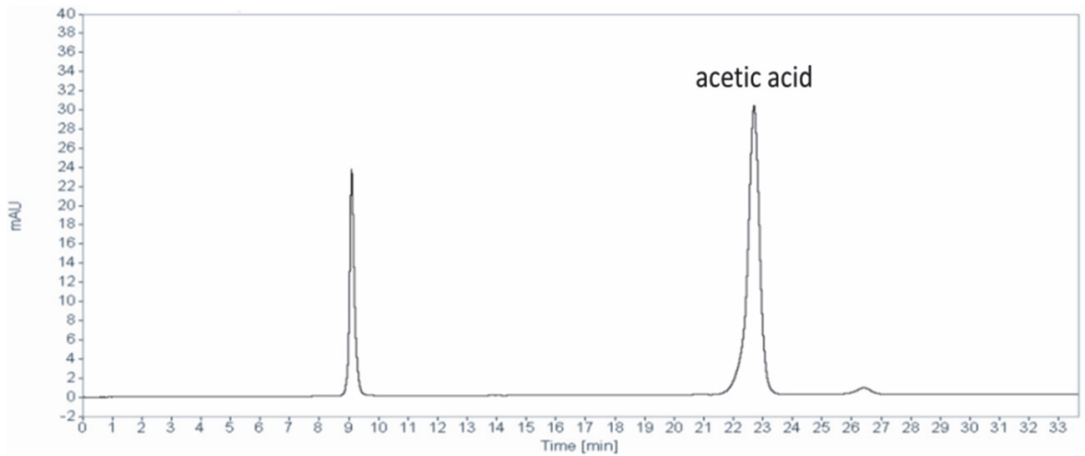

In vivo deracemization of $50 \mathrm{mM} \mathrm{rac-1a}$ using $12.5 \mathrm{mM}$ glucose after $18 \mathrm{~h}$ (RI detector, 1260 Infinity II LC System)

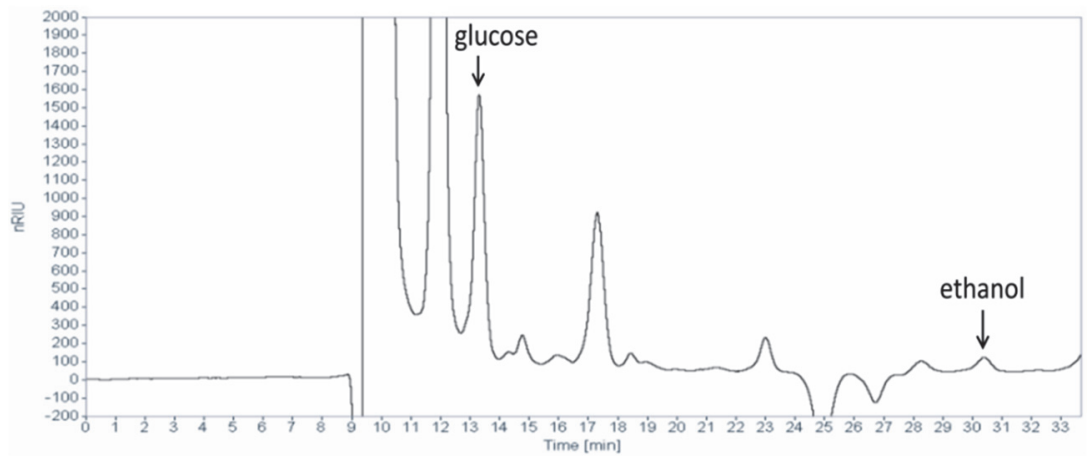


In vivo deracemization of $50 \mathrm{mM}$ rac-1a using $12.5 \mathrm{mM}$ glucose after $18 \mathrm{~h}$ (UV detector, 1260 Infinity II LC System)

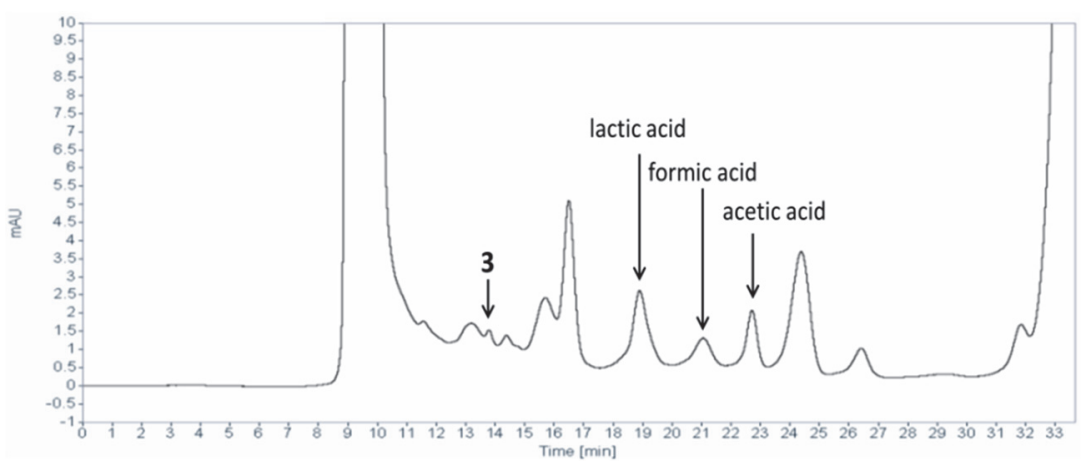

\section{References}

1. Park, E.-S.; Malik, M. S.; Dong, J.-Y.; Shin, J.-S. One-Pot Production of Enantiopure Alkylamines and Arylalkylamines of Opposite Chirality Catalyzed by $\omega$-Transaminase. ChemCatChem 2013, 5, 1734-1738.

2. Shin, J.-S.; Kim, B. G. Kinetic Modeling of $\omega$-Transamination for Enzymatic Kinetic Resolution of $\alpha$-Methylbenzylamine. Biotechnol. Bioeng. 1998, 60, 534-540.

3. Park, E.-S.; Kim, M.; Shin, J.-S. Molecular Determinants for Substrate Selectivity of $\omega$ Transaminases. Appl. Microbiol. Biotechnol. 2012, 93, 2425-2435.

4. Han, S.-W.; Park, E.-S.; Dong, J.-Y.; Shin, J.-S. Mechanism-Guided Engineering of $\omega$ Transaminase to Accelerate Reductive Amination of Ketones. Adv. Synth. Catal. 2015, 357, 1732-1740. 